\title{
Kesulitan Makan pada Pasien: Survei di Unit Pediatri Rawat Jalan
}

\author{
Soepardi Soedibyo, Raden Lia Mulyani \\ Pediatri Rawat Jalan, Departemen Ilmu Kesehatan Anak, Fakultas Kedokteran Universitas Indonesia - \\ Rumah Sakit Dr. Cipto Mangunkusumo Jakarta
}

Latar belakang. Masalah kesulitan makan pada anak sangat sering dihadapi baik oleh para orangtua maupun dokter atau petugas kesehatan yang lain, namun data mengenai kesulitan makan pada anak yang berobat di unit rawat jalan belum banyak diketahui.

Tujuan. Mengetahui prevalensi kesulitan makan berdasarkan kelompok usia, keluhan kesulitan makan, karakteristik anak, gejala klinis esofagitis refluks pada kesulitan makan, dan hubungan beberapa variabel ibu dan anak dengan kesulitan makan.

Metode. Penelitian cross-sectional dilakukan pada semua pasien yang datang ke Unit Pediatri Rawat Jalan antara bulan November 2007-Januari 2008. Data dikumpulkan menggunakan kuesioner dan pemeriksaan fisik. Pengambilan sampel dilakukan dengan consecutive sampling. Pengolahan data dengan program SPSS versi 13.

Hasil. Kelompok usia terbanyak mengalami kesulitan makan adalah usia 1 sampai 5 tahun (58\%), dengan jenis kelamin terbanyak laki-laki (54\%). Empat puluh tiga persen subjek memiliki status gizi kurang. Kesulitan makan didapatkan pada 50 orang dari 109 orang subjek (45,9\%). Gejala klinis esofagitis refluks ditemukan dalam jumlah yang sama (45,9\%). Keluhan berupa menghabiskan makanan kurang dari sepertiga porsi $(27,5 \%)$, menolak makan $(24,8 \%)$ dan anak rewel, merasa tidak senang atau marah $(22,9 \%)$, hanya menyukai satu jenis makanan $(7,3 \%)$ hanya mau minum susu $(18,3 \%)$, memerlukan waktu $>1$ jam untuk makan (19,3\%) dan mengemut (15,6\%). Keluhan $72 \%$ telah dialami lebih dari 6 bulan , 50\% memiliki keluhan gangguan kenaikan berat badan, 22\% rewel, 12\% nyeri epigastrium, 10\% back arching, dan 6\% nyeri menelan serta sering muntah.

Kesimpulan Anak dengan kesulitan makan terbanyak kelompok usia 1-5 tahun dan lebih sering pada anak laki-laki. Gejala kesulitan makan berturut-turut menghabiskan makanan kurang dari sepertiga porsi, menolak bila diberi makan, rewel, merasa tidak senang atau marah selama proses makan, memerlukan waktu lebih dari satu jam untuk makan, hanya mau minum susu, dan mengemut. Pasien yang mengalami esofagitis refluks gejala klinisnya gangguan kenaikan berat badan disusul oleh rewel/iritabel, nyeri epigastrium, back arching, nyeri menelan, dan muntah. (Sari Pediatri 2009;11(2):79-84).

Kata kunci: sulit makan, anak, rawat jalan

\footnotetext{
Alamat korespondensi

Prof. Dr. Soepardi Soedibyo, Sp.A(K). Pediatri Rawat Jalan Departemen Ilmu Kesehatan Anak FKUI. Divisi Nutrisi dan Metabolik. Departemen Ilmu Kesehatan Anak FKUI-RSCM. Jl. Salemba no. 6, Jakarta 10430. Telepon: 021-3915179. Fax: 021-3907743.
} akan merupakan kegiatan rutin seharihari yang jika dilihat sepintas tampaknya sangat sederhana, namun sebenarnya makan merupakan salah satu kegiatan 
biologis yang kompleks, melibatkan berbagai faktor fisik, psikologis, dan lingkungan. ${ }^{1}$ Selain sebagai upaya pemenuhan kebutuhan terhadap nutrien, makan juga memiliki fungsi psikologis dan sosial/edukasi yang dapat memberikan kepuasan bagi anak itu sendiri maupun bagi pemberinya. ${ }^{2}$

Kesulitan makan merupakan ketidakmampuan anak untuk mengkonsumsi sejumlah makanan yang diperlukannya, secara alamiah dan wajar, yaitu dengan menggunakan mulutnya secara sukarela. ${ }^{1,3,4}$ Masalah kesulitan makan sering dihadapi baik oleh para orangtua, dokter atau petugas kesehatan yang lain. Sekitar 25\%-40\% anak dilaporkan mengalami kesulitan makan. ${ }^{3-7}$ Penelitian terhadap anak prasekolah usia 4-6 tahun di Jakarta didapatkan prevalensi kesulitan makan sebesar 33,6\%, 44,5\% diantaranya menderita malnutrisi ringan- sedang, serta $79 \%$ telah berlangsung lebih dari tiga bulan. ${ }^{8}$ Penelitian di Belgia menemukan 17\% anak yang dirujuk dengan kesulitan makan yang parah ditemukan mengalami esofagitis refluks tanpa disertai

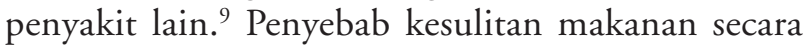
garis besar dibedakan oleh faktor organik, nutrisi, dan psikologis. ${ }^{1,3-5,9-11}$ Beberapa faktor tersebut dapat berdiri sendiri, namun sering kali multifaktorial.

Tata laksana kesulitan makan bersifat individual bagi masing-masing anak, namun pada dasarnya mencakup tiga aspek, yaitu identifikasi faktor penyebab, evaluasi dampak yang telah terjadi, serta upaya memperbaiki nutrisi dan faktor penyebab.

Berdasarkan ketiga hal tersebut, upaya yang dapat dilakukan adalah, ${ }^{1-6,10,11}$

- Mengatasi faktor penyebab (organik, neuromotor, infeksi, dan psikologik)

- Menangani dampak yang telah terjadi (malnutrisi atau defisiensi nutrien tertentu)

- Melakukan upaya nutrisi dengan memperbaiki asupan makanan,

- Reedukasi tentang perilaku makan pada anak maupun orangtua/keluarga ataupun pengasuh anak.

- Fisioterapi bagi anak yang mengalami kesulitan mengunyah/menelan baik karena faktor neurologik ataupun karena pembinaan keterampilan makan yang tidak adekuat.

Selain itu kunci utama keberhasilan tata laksana terletak pada orangtua atau pengasuh yang paling lama kontak dengan anak. Seringkali penyebab multi faktor, sehingga kesulitan makan tidak dapat diatasi dengan mudah, dan perlu tata laksana terpadu yang melibatkan berbagai disiplin ilmu. ${ }^{1-6,10,11}$ Kesulitan makan pada anak merupakan masalah yang serius karena dampak terhadap tumbuh kembang anak serta kemungkinan kualitas hidup kurang optimal. Deteksi dini masalah kesulitan makan sangat penting agar dampak negatif dapat dicegah dan tidak berkepanjangan.

\section{Metode}

Penelitian dilakukan di Unit Pediatri Rawat Jalan Departemen Ilmu Kesehatan Anak RSCM November 2007 sampai Januari 2008. Merupakan penelitian crosssectional untuk mengetahui masalah kesulitan makan pada pasien. Data dikumpulkan menggunakan kuesioner dan pemeriksaan fisik. Populasi target dan populasi terjangkau adalah semua pasien yang datang ke Unit Pediatri Rawat Jalan. Pengambilan sampel dilakukan dengan metode consecutive sampling. Orangtua atau pasien bersedia untuk ikut dalam penelitian dengan mengisi lembar kuesioner.

Data dicatat dalam formulir yang telah disediakan, kemudian dipindah-rekamkan dalam bentuk disket. Pengolahan data secara statistik dilakukan dengan program komputer Statistical Program for Social Science (SPSS) versi 13. Data deskriptif disajikan secara tekstular dan tabular dalam bentuk frekuensi dan persentase. Hubungan antar variabel dianalisis menggunakan uji $\mathrm{X}^{2}$.

\section{Hasil}

Selama kurun waktu penelitian didapatkan 109 subjek berasal dari pasien unit pediatri rawat jalan. Karakteristik subjek penelitian tertera pada Tabel 1 . Rerata usia subjek penelitian 4 tahun 8 bulan, 63,3\%. Ibu subjek penelitian sebagian besar adalah ibu rumah tangga $(62,4 \%)$ dengan tingkat pendidikan sedang $71,6 \%$, dan $41,3 \%$ memiliki pendapatan rendah. Riwayat regurgitasi ditemukan pada $35,8 \%$, dan riwayat pemakaian NGT/ETT ditemukan pada 8,3\%. Tidak ada subjek yang mengalami gizi buruk.

Keluhan kesulitan makan didapatkan pada 50 orang dari 109 orang subjek (45,9\%), semua memiliki gejala klinis esofagitis refluks. Gambaran kesulitan makan pada subjek tertera pada Tabel 2 dan 3 . 
Tabel 1. Karakteristik subjek penelitian

\begin{tabular}{|c|c|c|}
\hline Variabel & & $\mathrm{n}(\%)$ \\
\hline \multirow[t]{4}{*}{ Usia (tahun) } & $0-1$ & $14(12,8)$ \\
\hline & $1-5$ & $53(48,6)$ \\
\hline & $5-12$ & $36(33)$ \\
\hline & $12-18$ & $6(5,5)$ \\
\hline \multirow[t]{2}{*}{ Jenis kelamin } & Laki-laki & $69(63,3)$ \\
\hline & Perempuan & $40(36,7)$ \\
\hline \multirow[t]{2}{*}{ Pekerjaan ibu } & Ibu rumah tangga & $68(62,4)$ \\
\hline & Ibu bekerja & $41(37,6)$ \\
\hline \multirow[t]{3}{*}{ Pendidikan ibu } & Rendah & $13(11,9)$ \\
\hline & Sedang & $78(71,6)$ \\
\hline & Tinggi & $18(16,5)$ \\
\hline \multirow[t]{3}{*}{ Pendapatan keluarga } & Rendah & $45(41,3)$ \\
\hline & Sedang & $40(36,7)$ \\
\hline & Tinggi & $24(22)$ \\
\hline \multirow[t]{2}{*}{ Keluhan kesulitan makan } & Ya & $50(45,9)$ \\
\hline & Tidak & $59(54,1)$ \\
\hline \multirow[t]{3}{*}{ Usia kehamilan } & Kurang bulan & $5(4,6)$ \\
\hline & Cukup bulan & $102(93,6)$ \\
\hline & Lebih bulan & $2(1,8)$ \\
\hline \multirow[t]{2}{*}{ Berat lahir } & Rendah & $15(13,8)$ \\
\hline & Normal & $92(84,4)$ \\
\hline \multirow[t]{2}{*}{ Riwayat regurgitasi } & Ya & $39(35,8)$ \\
\hline & Tidak & $70(64,2)$ \\
\hline \multicolumn{3}{|l|}{ Riwayat pemakaian } \\
\hline (nasogastritic tube)/ & Ya & $9(8,3)$ \\
\hline (endotrakheal tube) & Tidak & $100(91,7)$ \\
\hline \multirow[t]{3}{*}{ Status gizi } & Buruk & $0(0)$ \\
\hline & Kurang & $47(43,1)$ \\
\hline & Baik/lebih/obesitas & $62(56,9)$ \\
\hline \multirow[t]{2}{*}{ Gejala klinis esofagitis refluks } & Ya & $50(45,9)$ \\
\hline & Tidak & $59(54,1)$ \\
\hline
\end{tabular}

Tabel 2. Keluhan kesulitan makan pada anak

\begin{tabular}{lc}
\hline \multicolumn{1}{c}{ Keluhan } & $\mathrm{n}(\%)$ \\
\hline Menolak bila diberi makan & $27(24,8)$ \\
Selama proses makan anak rewel, merasa tidak senang atau marah & $25(22,9)$ \\
Mempunyai kebiasaan makan yang aneh (makan kayu,rumput, tanah,dll) & $0(0)$ \\
Hanya menghabiskan makanan kurang dari sepertiga porsi & $30(27,5)$ \\
Hanya menyukai satu jenis makanan & $8(7,3)$ \\
Hanya mau minum susu & $20(18,3)$ \\
Mengemut makanan sebelum ditelan & $17(15,6)$ \\
Lebih dari satu jam untuk menyelesaikan makan & $21(19,3)$ \\
\hline
\end{tabular}

Subjek yang mengalami kesulitan makan $72 \%$ telah mengalami keluhan lebih dari 6 bulan (72\%). Riwayat regurgitasi ditemukan pada $44 \%$, dan riwayat pemakaian NGT/ETT 10\%. Sebagian besar subjek yang mengalami kesulitan makan memiliki status gizi kurang (58\%) dan memiliki gejala klinis 
Tabel 3. Gambaran gejala klinis esofagitis refluks pada anak dengan kesulitan makan

\begin{tabular}{lc}
\hline \multicolumn{1}{c}{ Keluhan } & Jumlah (\%) \\
\hline Muntah & $3(6)$ \\
Rewel (iritabel) & $11(22)$ \\
Back arching (melengkungkan & \\
$\quad$ punggung ke depan) & $5(10)$ \\
Nyeri epigastrium (nyeri ulu hati) & $6(12)$ \\
Nyeri dada & $0(0)$ \\
Disfagia (nyeri menelan) & $3(6)$ \\
Heartburn (ulu hati seperti terbakar) & $0(0)$ \\
Gangguan kenaikan berat badan & $25(50)$ \\
Hematemesis (muntah darah, berwarna & \\
$\quad$ merah/hitam) & $0(0)$ \\
Melena (buang air besar hitam) & $0(0)$ \\
Pucat & $6(12)$ \\
\hline
\end{tabular}

esofagitis refluks (72\%). Gambaran gejala klinis esofagitis refluks pada kesulitan makan tertera pada Tabel 3.

Tabel 4 menggambarkan hubungan beberapa variabel dengan kejadian kesulitan makan. Terdapat hubungan yang bermakna antara status gizi dengan kesulitan makan $(p=0,004)$. Hubungan yang bermakna juga ditemukan antara gejala klinis esofagitis refluks dengan kesulitan makan $(p=0,000)$.

Tidak terdapat hubungan yang bermakna antara usia, jenis kelamin, pendidikan ibu, pekerjaan ibu, pendapatan keluarga, usia kehamilan, berat lahir, riwayat regurgitasi, dan riwayat pemakaian NGT/ETT dengan kesulitan makan.

Tabel 4. Hubungan antara beberapa variabel dengan kesulitan makan

\begin{tabular}{|c|c|c|c|c|}
\hline \multirow[t]{2}{*}{ Variabel } & & \multicolumn{2}{|c|}{ Kesulitan makan } & \multirow[t]{2}{*}{$p$} \\
\hline & & Ya & Tidak & \\
\hline \multirow[t]{3}{*}{ Usia (tahun) } & $0-1$ & 5 & 9 & 0,194 \\
\hline & $1-5$ & 29 & 24 & \\
\hline & $5-18$ & 16 & 26 & \\
\hline \multirow[t]{2}{*}{ Jenis kelamin } & Laki-laki & 27 & 42 & 0,064 \\
\hline & Perempuan & 23 & 17 & \\
\hline \multirow[t]{2}{*}{ Pekerjaan ibu } & Ibu rumah tangga & 33 & 35 & 0,473 \\
\hline & Ibu bekerja & 17 & 24 & \\
\hline \multirow[t]{3}{*}{ Pendidikan ibu } & Rendah & 4 & 9 & 0,233 \\
\hline & Sedang & 35 & 43 & \\
\hline & Tinggi & 11 & 7 & \\
\hline \multirow[t]{3}{*}{ Pendapatan keluarga } & Rendah & 23 & 22 & 0,357 \\
\hline & Sedang & 19 & 21 & \\
\hline & Tinggi & 8 & 16 & \\
\hline \multirow[t]{3}{*}{ Usia kehamilan (bulan) } & Kurang & 2 & 3 & 1,000 \\
\hline & Cukup & 46 & 56 & \\
\hline & Lebih & 2 & 0 & \\
\hline \multirow[t]{2}{*}{ Berat lahir } & Rendah & 10 & 5 & 0,095 \\
\hline & Normal/lebih & 40 & 52 & \\
\hline \multirow[t]{2}{*}{ Riwayat regurgitasi } & Ya & 22 & 17 & 0,099 \\
\hline & Tidak & 28 & 42 & \\
\hline \multirow[t]{2}{*}{ Riwayat pemakaian NGT/ETT } & Ya & 5 & 4 & 0,730 \\
\hline & Tidak & 45 & 55 & \\
\hline \multirow[t]{3}{*}{ Status gizi } & Buruk & 0 & 0 & $0,004^{*}$ \\
\hline & Kurang & 9 & 18 & \\
\hline & Baik/lebih/obesitas & 21 & 1 & \\
\hline \multirow[t]{2}{*}{ Gejala klinis esofagitis refluks } & Ya & 36 & 14 & $0,000^{*}$ \\
\hline & Tidak & 14 & 45 & \\
\hline
\end{tabular}




\section{Diskusi}

Penelitian yang dilakukan di Unit Pediatri Rawat Jalan selama tiga bulan mengikutsertakan 109 orang anak dan prevalens kesulitan makan 45,9\%. Beberapa kepustakaan menyatakan prevalens kesulitan makan $25 \%-40 \% .^{3-7,12}$ Anak yang datang ke unit pediatri rawat jalan memiliki keluhan medis sehingga mempengaruhi nafsu makan maupun proses makan. Kepustakaan lain menyatakan kejadian kesulitan makan dapat meningkat menjadi 40\%-90\% pada anak dengan penyakit kronik dan gangguan neurologi. ${ }^{3-7,12}$

Prevalens terbesar kesulitan makan pada anak adalah kelompok usia 1-5 tahun (58\%). Pada usia balita terjadi perubahan pola makan dari makanan bayi ke makanan dewasa yang sesuai dengan perkembangan keterampilan anak dalam mengkonsumsi makanan. Pada masa balita ruang gerak dan lingkungan semakin luas, sehingga lebih banyak berhubungan dengan infeksi. Gabungan secara sinergis dapat menimbulkan masalah kesulitan makan. 1,3-5,9-11

Lamanya kesulitan makan pada anak sangat bervariasi, namun pada sebagian besar subjek (72\%) sudah berlangsung lebih dari 6 bulan dan $6 \%$ subjek berlangsung sekitar 3-6 bulan. Amirani ${ }^{8}$ mendapatkan $79 \%$ subjek mengalami kesulitan makan lebih dari 3 bulan.

Gambaran keluhan kesulitan makan pada subjek yang paling banyak adalah anak hanya menghabiskan makanan kurang dari sepertiga porsi $(27,5 \%)$. Gambaran lain yang ditemukan adalah menolak bila diberi makan, merasa tidak senang atau marah selama proses makan, memerlukan waktu lebih dari satu jam, hanya mau minum susu, dan mengemut makanannya sebelum ditelan. Beberapa data menyebutkan sekitar 27,3\% anak hanya mau makan lumat/cair, 24,1\% mengalami kesulitan menghisap, mengunyah atau menelan, 23,4\% anak memiliki kebiasaan makan yang aneh/ganjil, $11,1 \%$ tidak menyukai banyak macam makanan, $8 \%$ anak mengalami keterlambatan makan mandiri, dan 6,1\% anak mengalami mealtime tantrums. ${ }^{3,6}$

Penelitian sebelumnya terhadap anak usia prasekolah di Jakarta menemukan $44,5 \%$ anak yang mengalami kesulitan makan menderita malnutrisi ringan sedang (gizi kurang). ${ }^{8}$ Pada penelitian kami persentase anak dengan kesulitan makan yang mengalami gizi kurang agak lebih tinggi. Perbedaan terjadi karena perbedaan pengambilan sampel, anak sehat dan anak sakit.
Hasil analisis hubungan beberapa variabel dengan kejadian kesulitan makan menemukan hubungan antara status gizi dengan kesulitan makan. Sesuai dengan kepustakaan, kesulitan makan terutama yang sudah terjadi dalam waktu lama akan menimbulkan defisiensi nutrien yang menyebabkan malnutrisi. ${ }^{1,3,4,10,11}$

Penelitian di Belgia pada anak yang dirujuk dengan kesulitan makan ditemukan $17 \%$ mengalami esofagitis refluks tanpa disertai penyakit lain, ${ }^{9}$ sedangkan pada penelitian kami 72\%. Untuk dapat dibandingkan, kedua penelitian harus mempunyai definisi esofagitis refluks yang sama. Gambaran gejala klinis esofagitis refluks terbanyak pada subjek yang mengalami kesulitan makan adalah gangguan kenaikan berat badan (50\%). Anak yang menderita esofagitis refluks sekitar 10\%-28\% mengalami gagal tumbuh. ${ }^{13,14}$

Penelitian kami juga menemukan hubungan antara gejala klinis esofagitis refluks dengan kesulitan makan. Salah satu faktor yang dapat menimbulkan kesulitan makan adalah faktor organik, diantaranya refluks gastroesofagus yang menyebabkan disfagi. ${ }^{1,3-6,9-11}$

\section{Kesimpulan}

Prevalens kesulitan makan pada anak yang datang ke unit pediatri rawat jalan 45,9\% dengan prevalens 58\% pada kelompok usia 1-5 tahun. Keluhan terbanyak adalah anak hanya menghabiskan makanan kurang dari sepertiga porsi $(27,5 \%)$. Gangguan kenaikan berat badan terbanyak ditemukan (50\%). Gejala lain yang ditemukan adalah rewel/iritabel (22\%), nyeri epigastrium (12\%), back arching (10\%), nyeri menelan $(6 \%)$, dan muntah $(6 \%)$. Terdapat hubungan antara status gizi dengan kesulitan makan dan antara gejala klinis esofagitis refluks dengan kesulitan makan.

\section{Daftar Pustaka}

1. Samsudin. Anoreksia pada anak: aspek pediatrik. Dalam: Firmasyah A, Boediarso A, Suharyono, Sunoto, penyunting. Optimalisasi tata laksana gagal tumbuh gastrointestinal guna meningkatkan kualitas sumber daya manusia. Jakarta: Balai Penerbit FKUI;1994.h.25-35.

2. Boediarti B. Mengatasi kesulitan makan pada anak. Diunduh dari: www.google.com. Diakses tanggal 20 Februari 2008.

3. Nasar SS. Masalah makan pada anak. Dalam: Pulungan 
AB, Hendarto A, Hegar B, Oswari H, penyunting. Nutrition growth development. Jakarta: CPD IDAI Jaya; 2006.h.53-68.

4. Judarwanto W. Jangan meremehkan kesulitan makan anak. Diunduh dari:www.google.com. Diakses tanggal 20 Februari 2008.

5. Bonnin AC. Feeding problem of infant and toddlers. Can Fam Physician 2006;52:1247-51.

6. Palmer S, Horn S. Feeding problem in children. Dalam: Palmer S, Ekvall S, penyunting. Pediatric Nutrition in Developmental Disorders. Springfield: Charles C. Thomas publ; 1978.h.107-29.

7. Kerr S. Fundamental of feeding children. Diunduh dari: www.google.com. Diakses tanggal 20 Februari 2008.

8. Amirani DF. Kesulitan makan pada anak prasekolah usia 4-6 tahun:prevalens, karakteristik, antropometris dan keluarga. Tesis. Program Studi Ilmu Kesehatan Anak FKUI, 1998, Jakarta.

9. Rommel N, Meyer AM, Feenstra L, Wauters GV. The complexity of feeding problems in 700 infants and young children presenting to a tertiary care institution. J Pediatr Gastroenterol Nutr 2003;37:75-84.

10. Wiharta SA. Masalah kesulitan makan pada anak. Cermin Dunia Kedokteran 1982;27:11-4.

11. Darmoutomo E. Menyiasati anak sulit makan. Diunduh dari: www.google.com. Diakses tanggal 20 Februari 2008.

12. Sullivan PB, Lambert B, Rose M, Adams MF, Johnson A, Griffiths P. Prevalence and severity of feeding and nutritional problems in children with neurological impairment: Oxford feeding study. Develop Med \& Child Neurol 2000;42:674-80.

13. Salvatore S, Vandenplas Y. Gastro-oesophageal reflux disease and motility disorders. Best Practice and Research Clin Gastroenterol 2003;17:163-79.

14. Costa AJF, Silva GAP, Gouvela PAC, Filho EMP. Prevalence of pathologic gastroesophageal reflux in regurgitant infant. J Pediatr 2004;80:291-5. 